\title{
THE ROLE OF DAIRY COOPERATIVES IN REDUCING WASTE OF DAIRY PRODUCTS IN THE LUBELSKIE VOIVODESHIP*
}

\author{
Maria Zuba-Ciszewska ${ }^{\bowtie}$ \\ John Paul II Catholic University of Lublin, Poland
}

\begin{abstract}
The purpose of this paper was to determine the role of dairy cooperatives which are a crucial factor in reducing losses of dairy products at the distribution stage of the dairy production chain in the Lubelskie voivodeship. The research was conducted on local data provided by one of the largest Polish supermarket chains. In the Lubelskie voivodeship, dairy products are manufactured in 18 plants, including 14 dairy cooperative members. Basic dairy products are mainly supplied by local dairies, especially by dairy cooperatives. Operators based outside the Lubelskie voivodeship supply the majority of processed milk products. The greatest product losses are related to products supplied by dairies based outside the voivodeship. The main cause of dairy product loss in the supply chain was product expiry. On average, the largest share of expired products (excluding desserts) was noted for goods supplied by dairies based outside the voivodeship. As regards most products supplied from outside the voivodeship, their share in losses exceeds their share in sales (by a few or up to several dozen percent). The retail chain covered by this study mainly relies on a wide range of basic local dairy products offered by Lublin dairies, especially including dairy cooperatives. These suppliers continue to be an important link in the regional dairy chain.
\end{abstract}

Keywords: dairy cooperatives, waste of dairy products, local market

\section{INTRODUCTION}

The Polish dairy cooperative movement has a long history dating back over 100 years (Inglot, 1971). During that time, it has gained vast experience and expertise, earning credibility and trust of both cooperative members and customers (Zuba-Ciszewska, 2016). In 2015, there were 241 milk processing plants, including 177 with more than 10 employees. While at least a few dairy plants operate in every region of the country, a concentration of these activities is noticeable in a strip of voivodeships extending from the southwest through central Poland to the three voivodeships in the east (Fig. 1).

Domestic dairy cooperatives remain the most important type of enterprise in the dairy sector. As a result of changes in the milk processing sector taking place since mid-1990s (Seremak-Bulge, 2005), their share in the purchasing and processing of milk has been reduced from $100 \%$ to approximately $66 \%$. However, nearly $61 \%$ of dairy plants (i.e. 147) still operate as cooperatives. Dairy cooperatives are concentrated in regions with a large or very large overall number of dairy plants. This confirms the crucial role of cooperatives in the Polish dairy industry, strengthened by experience and a longstanding tradition. The Podlaskie voivodeship, home of the two largest dairy cooperative groups (Mlekovita and

*Statutory Research Fund of the Department of Banking and Finance.

$凶$ PhD Maria Zuba-Ciszewska, Department of Banking and Finance, John Paul II Catholic University of Lublin, Al. Racławickie 14, 20-950 Lublin, Poland, e-mail: maria.zuba@kul.pl 


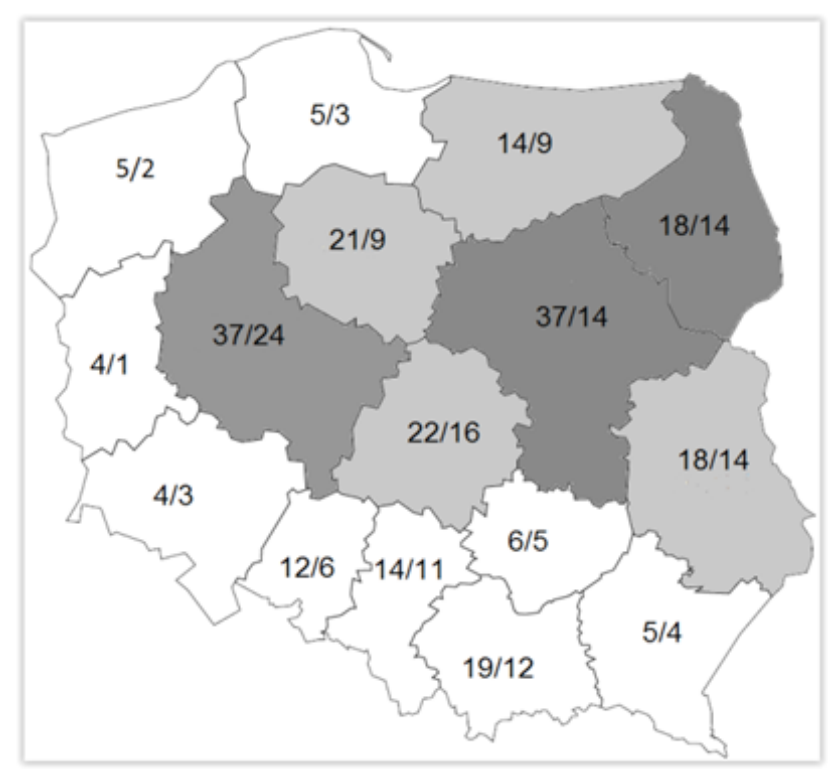

Fig. 1. Dairy processing plants in Poland in 2015. Legend: Total number of dairy processing plants / cooperative dairy processing plants, Dark grey - regions with the highest level of cow's milk production

Source: own elaboration based on GUS, 2016; Sznajder, 2016.

Mlekpol), has gained considerable importance in this area. They run more than twenty branches in ten other regions of the country, bolstering the local dairy markets. Nearly all regions hosting a large number of dairy plants (except for the Śląskie and Małopolskie voivodeships) access a strong raw materials base, with three voivodeships (Mazowieckie, Podlaskie ${ }^{1}$ and Wielkopolskie) accounting for nearly $54 \%$ of the domestic milk production volume.

In response to changing market conditions-such as consumer preferences-dairies, including cooperatives, have been expanding their product range. The consumption of processed dairy products is growing, partially because of continuous product innovation and intensive promotional measures emphasizing their value added (health benefits) (Chudzian, 2012). These are significant factors, as research shows that new experiences around food product innovations have a considerable effect on purchasing behavior (Lundahl, 2012). On the other hand, production of healthy food is a factor that

\footnotetext{
${ }^{1}$ Nearly the entire Podlaskie voivodeship, as the only one of those named, is expanding its dairy farming and milk production (Parzonko, 2013).
}

may significantly influence the development and competitiveness of dairy enterprises in Poland (Firlej, 2008). Hence, in addition to basic products, Polish dairies are attempting to offer more processed products, following the example of other countries (MacDonald et al., 2010). In recent years, the phenomenon of 'consumer ethnocentrism' can be observed as well in relation to domestic or even local dairy products. Consumers choose these products not only because of the quality of raw materials originating from a clean environment, as is the case with Polish products, but also for economic reasons, as pointed out by the authors of the concept, Shimp and Sharma (1987). These reasons include the use of local productive inputs (labor and capital) and better production outcomes in the form of sales revenue and profits earned by the local or domestic dairy industry. This type of consumer behavior with respect to agri-food products was pointed out 60 years ago by Pilgrim (1957) who claimed that food purchasing decisions are influenced not only by food properties and personal factors but also by environmental determinants (Steenkamp, 1997).

Consumers can benefit from a wider range of products while perceiving them as strong Polish brands, which is enabled by the concentration of the dairy sector (Brodziński, 2014) in dairy groups, mainly cooperatives. For the dairy sector, consolidation is an important driver of competitiveness in the market (Pietrzak, 2006; Sznajder, 1999), resulting in numerous advantages, including benefits for consumers (Zalewski, 2000). Nevertheless, it entails the risk that manufacturers will exploit their strong market position to the detriment of farmers. An effective way of counteracting such developments is the cooperation between farmers and cooperatives (MacDonald and McBride 2010), because the main role of cooperatives is to look after the interests of their members. The cooperative movement is also based on ideological values (democracy, equality and self-help) and ethical values (fairness, honesty, care, and commitment to cooperative ideas) connected with cooperative principles (voluntariness, comanagement, autonomy, learning and personal development for the benefit of the cooperatives, cooperation) (Czternasty, 2013). Many of these have a practical aspect, mainly involving cooperation between cooperatives and farms to increase management efficiency.

Food waste remains a significant problem worldwide. One third of food produced for human consumption is lost or wasted globally (about 1.3 billion tons per year). Food losses represent a waste of resources used in 
production (FAO, 2011). Food is lost or wasted throughout the supply chain, from agricultural production down to household consumption. ${ }^{2}$ Global losses in utilization of milk increased by $83 \%$ over a period of 20 years, to a level of over 19 million tons in 2013 (FAO, 2017). Europe accounts for one of the smallest shares of waste in this commodity group (FAO, 2011). Waste occurs at each stage of the dairy production chain i.e. milk production (in farms), processing (in dairy plants), distribution (retail stores) and consumption (households). Globally, the greatest percentage of waste in the dairy product supply chain occurs at the stages of distribution and consumption (FAO, 2011). There is also considerable waste at the stages of agricultural production and postharvest handling and storage, resulting from decreased milk production due to dairy cow illness (mastitis) and spillage and degradation during transport between farms and dairies. The least waste is generated at the processing and packaging stages, and involves spillage during industrial milk treatment (e.g. pasteurization) and milk processing, e.g. for cheese and yoghurt production (FAO, 2011). Dairy products are classified as perishable goods, so continuous and prompt delivery is of great importance in the sale of these products, which can be ensured by local dairies. These entities form a Local Food System (LFS) where food is produced, processed and sold in a specific geographic area (Kneafsey et al., 2013), although the definition of the area can vary depending on the region and its characteristics (Martinez et al., 2010). As emphasized, e.g. by Ross et al. (1999) or Marsden et al. (2000), this system can be an opportunity for agricultural development. At the same time, its operation depends on defining the parties and on real and regular economic interactions (Swenson, 2009). Note also that local products can improve food security in the local community by increasing access to fresh food (Martinez et al., 2010).

\section{RESEARCH METHODOLOGY}

The purpose of this paper was to determine the role of dairy cooperatives which are a crucial factor in reducing losses of dairy products at the distribution stage of the dairy production chain in a local market. In this context,

${ }^{2}$ Food losses occurring at the end of the food chain (retail and final consumption) are known as 'food waste,' which refers to retailers' and consumers' behaviour (Parfitt et al., 2010). 'local' refers to the location of the cooperative in a given region rather than to its operation scope, because many of them sell their products both in Poland and internationally. This is reflected in exports of Polish dairy products which have increased six-fold over the last decade, while their value has increased nearly twofold, exceeding EUR 1.65 billion. The research was conducted on data from two consecutive years (2014 and 2015), provided by one of the largest Polish supermarket chains ${ }^{3}$. The chain consists of several hundred stores located in all voivodeships and sells food products from local suppliers. The study area was narrowed to the Lubelskie voivodeship because the selected retail chain operates a large number of stores (over 50) in this region, offering dairy products from local manufacturers to customers. Moreover, there are many dairies in this voivodeship. Dairy products are manufactured in 18 plants (A, $\mathrm{B}, \mathrm{C})$, including 14 dairy cooperative members $\left(\mathrm{A}^{4}, \mathrm{~B}^{5}\right)$. Among the nine dairy cooperatives operating in the area, three have two plants. Also, the Lubelskie voivodeship is home to two dairy cooperatives from the Mlekovita group based in the Podlaskie voivodeship. This study covers two aspects: the share of specific dairy groups in the sales volume (dairy cooperatives in the Lubelskie voivodeship: group A; Lublin-based branches of the Mlekovita cooperative: group B; other, non-cooperative dairies in the Lubelskie voivodeship: group $\mathrm{C}$; and operators from outside the voivodeship: group D) and the issue of food waste. It was posited that the level of food waste is lower in stores selling products from local dairies due to fast, continuous supply. This is important because most dairy products have a short shelf life (Litwińczuk, 2004). The role of expired products (one of the main reasons for food losses) was determined as well. These losses do not only exclude food products from consumption but also entail costs borne by retail chains rather than by producers (Grochowska, 2015; Wrzosek et al., 2014).

${ }^{3}$ The chain elected not to be named in the study.

${ }^{4}$ Piaski Regional Dairy Cooperative, Krasnystaw Regional Dairy Cooperative and its branch in Zamość, Bychawa Regional Dairy Cooperative, Spomlek Dairy Cooperative and its branch in Parczew, Ryki Dairy Cooperative, Michowianka Dairy Cooperative, Janów Lubelski Regional Dairy Cooperative, Opole Lubelskie Regional Dairy Cooperative and its branch in Kraśnik, Bieluch Dairy Cooperative.

${ }^{5}$ Biała Podlaska, Tomaszów Lubelski. 


\section{RESEARCH RESULTS}

The correlation between the type of dairy product sold and its origin is clearly evident in the Lubelskie voivodeship supermarket chain covered by this study. Basic dairy products are mainly supplied by local dairies, while processed dairy products are supplied mostly by dairies from outside the voivodeship (Table 1).

In 2015, Lublin-based dairy cooperatives (including the two Mlekovita members) supplied 59\% of pasteurized liquid milk ( $8 \%$ less than in 2014 ), nearly $78 \%$ of basic fermented beverages such as kefir, buttermilk and soured milk (an increase by over $4 \%$ compared to 2014 ),
$64 \%$ of sour cream and sweet cream (5\% more than in the previous year), and $50 \%$ of butter and milk fat (7\% less than in 2014). Only cheese and cottage cheese, accounting for nearly two thirds of the sales volume, are supplied by dairy plants from outside the region. Nearly all the dairy cooperatives in Lublin include most basic dairy products in their product range (from 3 to 5 types of products). Only a few of them manufacture yoghurt or processed cheese. Thus, Lublin-based dairies hold a small share in the production of processed dairy products. Furthermore, no dairy plant in Lublin manufactures desserts, so they do not hold any share in the corresponding sales volume. Another striking finding is

Table 1. Quantitative share in sales of products from various suppliers in stores of the retail chain covered by this study in the Lubelskie voivodeship (\%)

\begin{tabular}{|c|c|c|c|c|c|c|}
\hline \multirow{2}{*}{ Quantitative share } & & \multicolumn{4}{|c|}{ Suppliers of dairy products } & \multirow{2}{*}{$\begin{array}{c}(\mathrm{A}+\mathrm{B}+\mathrm{C}+\mathrm{D}) \\
\text { total sales }\end{array}$} \\
\hline & & $\mathrm{A}$ & $\mathrm{B}$ & $\mathrm{C}$ & $\mathrm{D}$ & \\
\hline \multirow[t]{2}{*}{ Pasteurized liquid milk } & 2014 & 47.25 & 19.77 & 0.60 & 32.39 & 100 \\
\hline & 2015 & 36.10 & 22.90 & 0.01 & 40.99 & 100 \\
\hline \multirow[t]{2}{*}{ Kefir, buttermilk and soured milk } & 2014 & 73.26 & 0.00 & 5.09 & 21.65 & 100 \\
\hline & 2015 & 75.45 & 2.23 & 5.99 & 16.34 & 100 \\
\hline \multirow[t]{2}{*}{ Sour cream and sweet cream } & 2014 & 46.42 & 12.45 & 0.00 & 41.14 & 100 \\
\hline & 2015 & 44.57 & 19.48 & 0.00 & 35.95 & 100 \\
\hline \multirow[t]{2}{*}{ Cottage cheese } & 2014 & 27.51 & 5.38 & 3.36 & 63.75 & 100 \\
\hline & 2015 & 28.64 & 5.70 & 2.21 & 63.45 & 100 \\
\hline \multirow[t]{2}{*}{ Butter and milk fat } & 2014 & 32.76 & 10.14 & 3.05 & 54.04 & 100 \\
\hline & 2015 & 12.95 & 37.29 & 7.43 & 42.34 & 100 \\
\hline \multirow[t]{2}{*}{ Yoghurt and milk beverages } & 2014 & 24.05 & 2.68 & 0.00 & 73.28 & 100 \\
\hline & 2015 & 23.88 & 5.24 & 2.39 & 68.48 & 100 \\
\hline \multirow[t]{2}{*}{ Ripened cheese } & 2014 & 7.39 & 0.00 & 0.00 & 92.61 & 100 \\
\hline & 2015 & 8.50 & 0.00 & 0.00 & 91.50 & 100 \\
\hline \multirow[t]{2}{*}{ Processed cheese } & 2014 & 8.62 & 5.39 & 24.61 & 61.39 & 100 \\
\hline & 2015 & 7.99 & 6.22 & 21.68 & 64.11 & 100 \\
\hline \multirow[t]{2}{*}{ Dairy desserts } & 2014 & 0 & 0 & 0 & 100 & 100 \\
\hline & 2015 & 0 & 0 & 0 & 100 & 100 \\
\hline
\end{tabular}

A - dairy cooperatives in the Lubelskie voivodeship; B - branches of the Mlekovita cooperative; $\mathrm{C}$ - other dairies in the Lubelskie voivodeship; D - suppliers from outside the voivodeship.

Source: own elaboration. 
Zuba-Ciszewska, M. (2018). The role of dairy cooperatives in reducing waste of dairy products in the Lubelskie voivodeship. J. Agribus. Rural Dev., 1(47), 97-105. http://dx.doi.org/10.17306/J.JARD.2018.00401

a low share in sales of ripened cheese $(8.5 \%$ in 2015$)$. Apart from access to products (manufactured by 10 dairies, including brands recognized outside Poland, such as Spomlek Dairy Cooperative, Ryki Dairy Cooperative and Michowianka Dairy Cooperative), this might result from other factors, such as price or form of packaging. To sum up, processed dairy products are supplied by operators from outside the voivodeship.

The research showed considerable differences in the wastage of dairy products in the retail chain (Table 2). The largest food losses reached several dozen tons a year (nearly 79 tons of yoghurt and 49 tons of cottage cheese in 2015), while the lowest levels did not exceed a few tons ( 2 tons of sour cream and sweet cream and 5 tones of ripened cheese). As regards most of the products offered, the largest losses were noted for those supplied by dairies from outside the region. This is true for products supplied primarily by this type of operators, i.e. processed products (yoghurt and milk beverages, ripened cheese, processed cheese, and milk desserts) as well as cottage cheese. These dairies also report greater wastage of butter and milk fat, even though their dominance in the supply of these products is gradually decreasing. In the case of pasteurized liquid milk, kefir, butter milk, soured milk, sour cream and sweet cream, the chain incurred the greatest losses on products supplied by dairy cooperatives from the Lubelskie voivodeship. The volume of losses on products supplied by operators from outside the region is from 1.4 to 50 times greater than on locally supplied products. In cases where the losses

Table 2. Waste of products from various suppliers in stores in the Lubelskie voivodeship

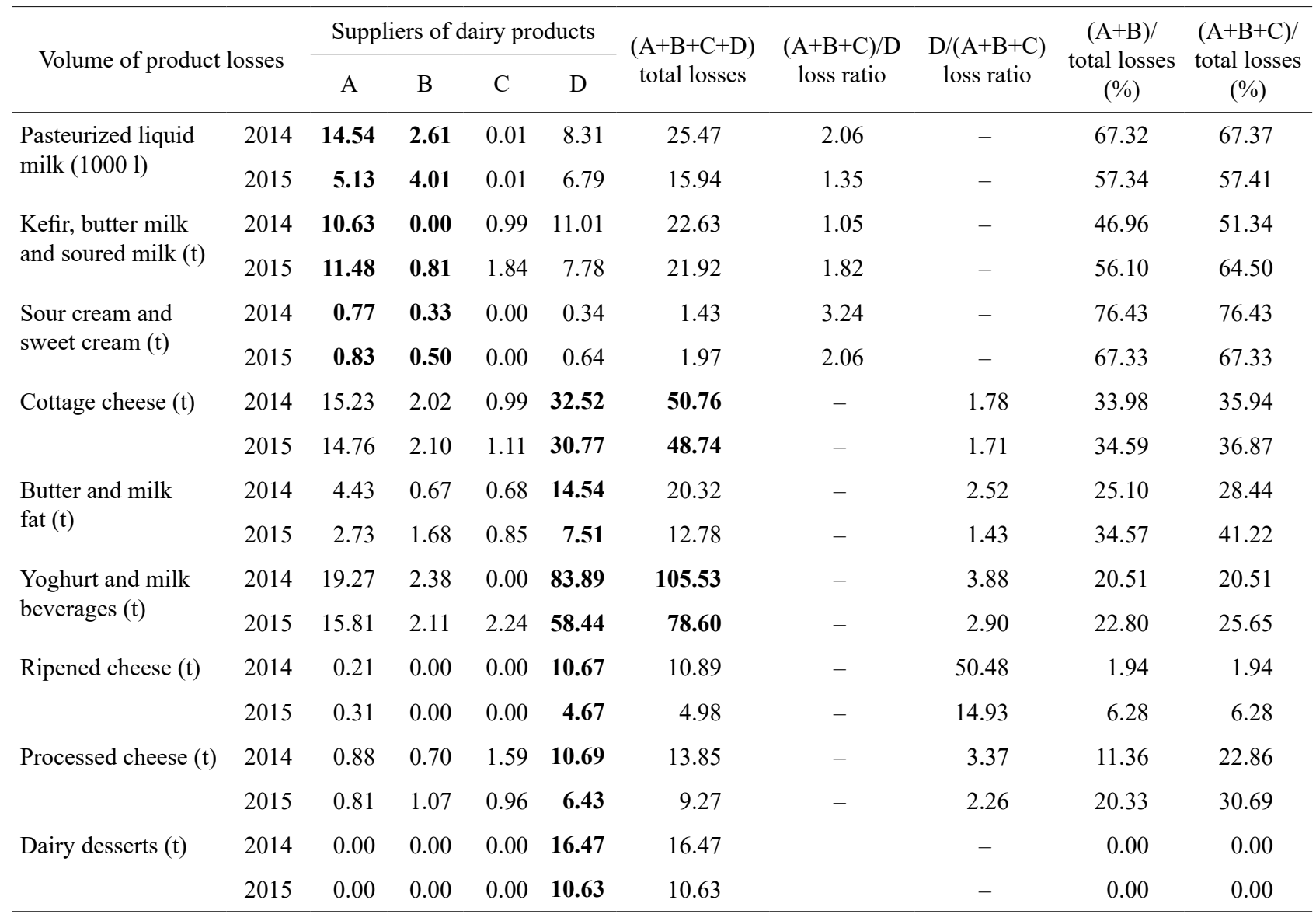

Legend as for Table 1.

Source: own elaboration. 
Zuba-Ciszewska, M. (2018). The role of dairy cooperatives in reducing waste of dairy products in the Lubelskie voivodeship. J. Agribus. Rural Dev., 1(47), 97-105. http://dx.doi.org/10.17306/J.JARD.2018.00401

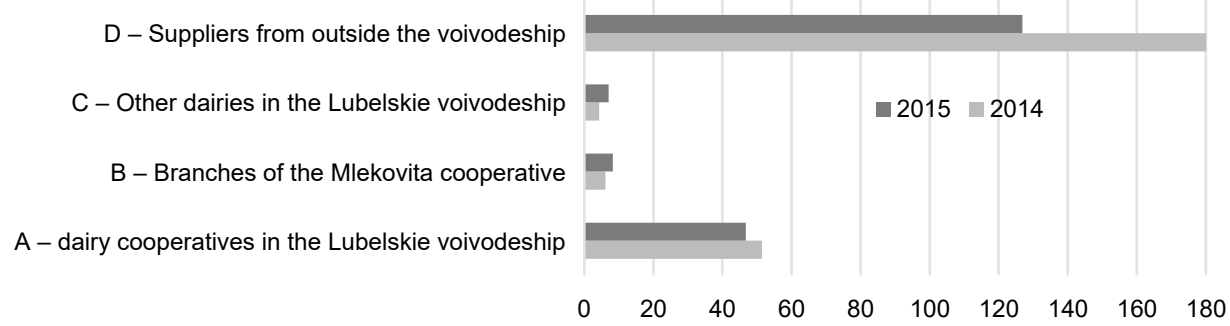

Fig. 2. Waste of dairy products* from various dairies in the retail chain $(\mathrm{t})$. *Excluding pasteurized liquid milk

Source: own elaboration.

Table 3. Expired products in total wastage of dairy products $(\%)$

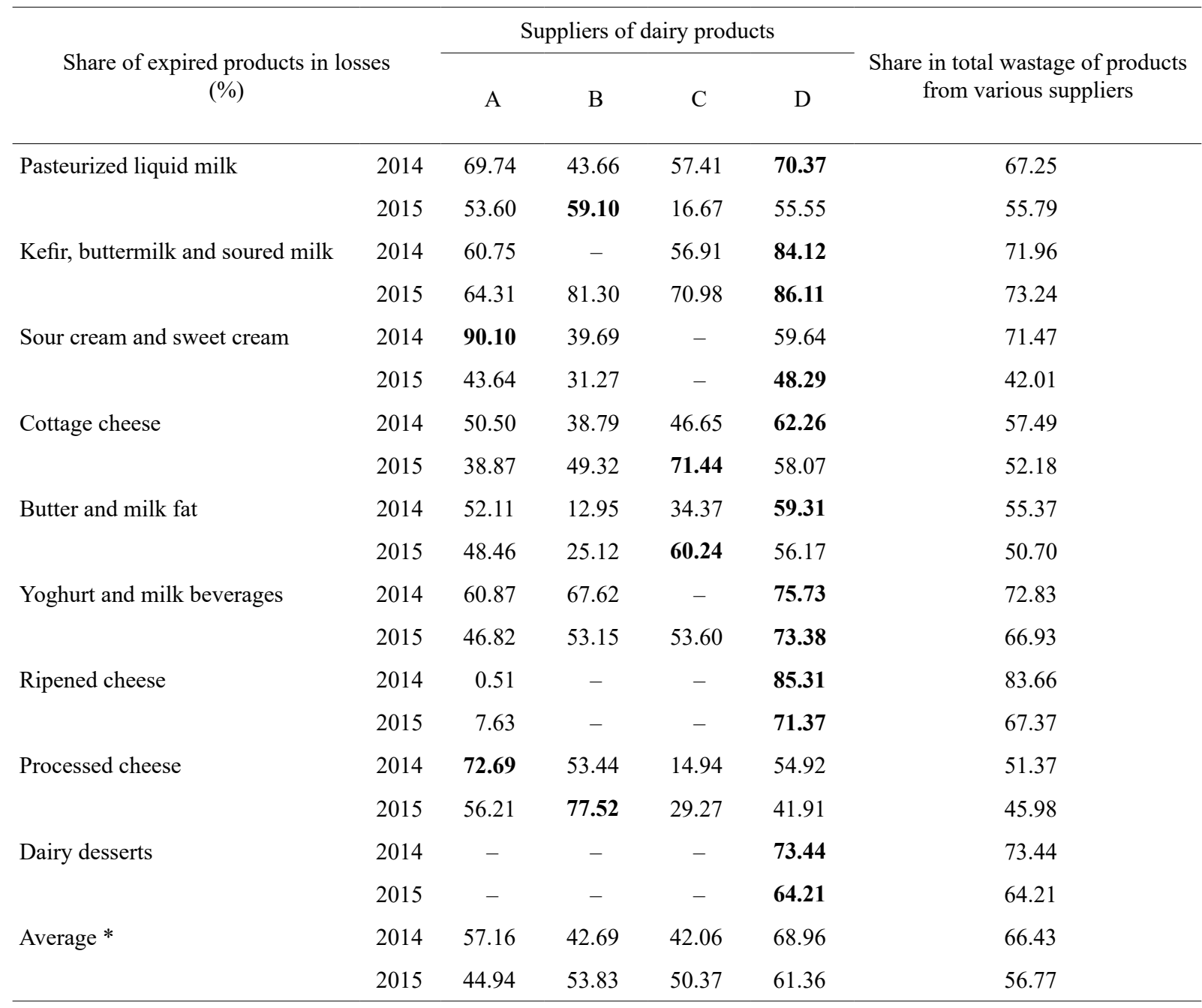

No product loss.

* Excluding desserts.

Source: own elaboration. 
Zuba-Ciszewska, M. (2018). The role of dairy cooperatives in reducing waste of dairy products in the Lubelskie voivodeship. J. Agribus. Rural Dev., 1(47), 97-105. http://dx.doi.org/10.17306/J.JARD.2018.00401

on local products are greater (for milk, basic fermented beverages, sour cream and sweet cream), the difference is markedly smaller (ranging from 1.1 to 3 times).

In 2015 , the wastage of products supplied by local dairies amounted to 9,000 liters of pasteurized liquid milk and 62 tons of other items (Fig. 2). In the case of dairies from outside the region, the corresponding volume is much higher (although lower than in 2014), reaching 127 tons and 7,000 liters of milk. In conclusion, the loss of products from local dairies, including dairy cooperatives, is considerably lower than in the case of dairies from outside the region.

Expiry is the main reason behind wastage of dairy products (Table 3). In 2015, the share of expired products in the total volume of losses ranged from $42 \%$ (sour cream and sweet cream) to $73 \%$ (basic fermented beverages). In most cases, products supplied by local dairy cooperatives had a smaller share in losses incurred for this reason in 2015 than products supplied by cooperatives from outside the region (except milk and processed cheese). This is why the largest average share of expired products (except desserts) in total losses was noted for products supplied by dairy plants from outside the voivodeship (61\% in 2015), compared to $50 \%$ for the three types of Lublin-based dairies, and among these, $45 \%$ for the local dairy cooperatives.

The volume of product loss by group of dairies depends on their supply volumes (Fig. 3). In the case of pasteurized liquid milk, basic fermented products, sour cream and sweet cream, the chain incurred the greatest losses on products supplied mainly by Lublin-based dairies. In the case of butter and milk fat, supplied mostly by local entities, the greatest losses were generated by products from outside the voivodeship. The greater the supply volume of processed products from dairies from outside the voivodeship, the higher are the losses.

As shown by the comparison between the dairies' share in losses and share in sales, in most cases, the proportion of products from non-local dairies in total losses exceeds their share in sales (by a few to a few dozen

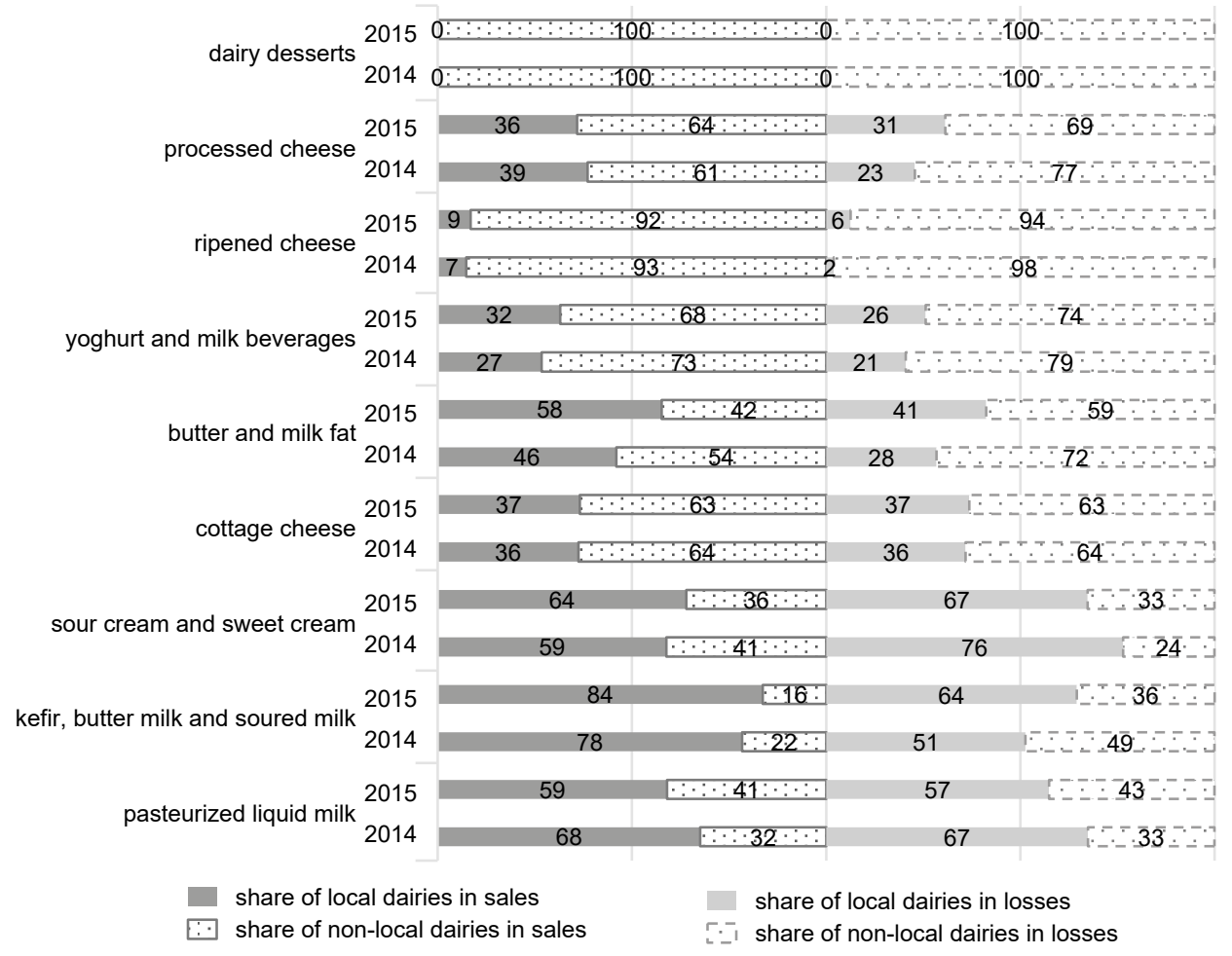

Fig. 3. Share of dairy products from various dairies in total losses incurred by the retail chain, and in the chain's sales (\%)

Source: own elaboration. 
percent). The share in sales is equal to the share in losses only in the case of cottage cheese (63\% in 2015), and is greater than the share in losses in the case of sour cream and sweet cream (by $3 \%$ in 2015).

\section{SUMMARY AND CONCLUSIONS}

Basic dairy products are mainly supplied by local dairies, especially by dairy cooperatives. Nearly all of them offer the majority of basic dairy products, while only a small percentage of them offer processed products (except for ripened cheese). Operators based outside the Lubelskie voivodeship supply the majority of processed milk products (yoghurt and milk beverages, ripened cheese, processed cheese, and dairy desserts), as well as cottage cheese. The greatest product losses are related to products supplied by dairies based outside the voivodeship. This is true for products supplied primarily by this type of operators, as well as for butter and milk fat. The total wastage of products supplied by local dairy plants is significantly lower than in the case of suppliers from outside the region. The main cause of dairy product loss in the supply chain was product expiry. On average, the largest share of expired products (excluding desserts) was noted for goods supplied by dairies based outside the voivodeship. The volume of product loss by group of dairies depends on their supply volumes. The greater the supply volume of processed products from dairies from outside the voivodeship, the higher are the losses. Furthermore, most products supplied from outside the voivodeship have a greater share in losses than in sales (by a few to a few dozen percent). The retail chain covered by this study mainly relies on a wide range of local basic dairy products offered by Lublin dairies, especially including dairy cooperatives. These suppliers continue to be an important link in the regional dairy chain. By selling their products, the stores incur smaller food losses, because the nature of dairy products requires swift and continuous supply, which is guaranteed by local dairies.

\section{REFERENCES}

Brodziński, M. G. (2014). Oblicza polskiej spółdzielczości wiejskiej. Geneza - rozwój - przyszłość [Aspects of Polish rural cooperatives. Genesis - development - future] (p. 214, 361). Warszawa: Wyd. Frel [in Polish].
Chudzian, J. (2012). Uwarunkowania spożycia produktów mleczarskich [Determinants of consumption of dairy products]. Zesz. Nauk. SGGW Polit. Eur. Fin. Mark., 7(56), 23 [in Polish].

Czternasty, W. (2013). Determinanty rozwoju spółdzielczości w różnych warunkach ekonomiczno-społecznych [Determinants of cooperative development in various economic and social conditions] (p. 82). Toruń: Wyd. Adam Marszałek [in Polish].

FAO (2011). Global food losses and food waste - Extent, causes and prevention (p. V, 2-3, 26-27). Rome: FAO.

FAO (2017). Retrieved April 10th 2017 from: http://www.fao. org/faostat/en/

GUS (2016). Rocznik Statystyczny Rolnictwa 2015 [Central Statistical Office, Statistical yearbook of agriculture 2015]. Retrieved from: http://stat.gov.pl/obszary-tematyczne/roczniki-statystyczne/roczniki-statystyczne/rocznik-statystyczny-rolnictwa-2015,6,9.html

Firlej, K. (2008). Wpływ otoczenia zewnętrznego na rozwój i konkurencyjność przedsiębiorstw przemysłu spożywczego - wyniki analizy scenariuszowej [The influence of the external environment on the development and competitiveness of food industry enterprises - the results of the scenario analysis]. In: I. Szczepaniak (Ed.), Wybrane aspekty konkurencyjności polskich producentów żywności [Selected aspects of competitiveness of Polish food producers] (p. 75-100). Warszawa: IERiGŻ-PIB [in Polish].

Grochowska, R. (Ed.). (2015). Ocena strat ponoszonych na poszczególnych etapach łańcucha mleczarskiego w Polsce. Studia i Monografie 162 [Assessment of losses incurred at individual stages of the dairy chain in Poland. Studies and Monographs 162] (p. 110). Warszawa: IERiGŻ-PIB [in Polish].

Inglot, S. (Ed.). (1971). Zarys historii polskiego ruchu spółdzielczego. Cz. I - do 1918 [Outline of the history of the Polish cooperative movement. Part I - until 1918]. Warszawa: Zakład Wydawnictw Centrali Rolniczej Spółdzielni ,Samopomoc Chłopska” [in Polish].

Kneafsey, M., Venn, L., Schmutz, U., Balázs, B., Trenchard, L., Eyden- Wood, T., Bos, E., Sutton, G., Blackett, M. (2013). Short Food Supply Chains and Local Food Systems in the EU. A State of Play of their Socio-Economic Characteristics (p. 23). Luxembourg: EC.

Litwińczuk, Z. (Ed.) (2004). Surowce zwierzęce. Ocena i wykorzystanie [Animal raw materials. Assessment and use]. Warszawa: PWRiL [in Polish].

Lundahl, D. (2012). Breakthrough food product innovation. Through emotions research (p. 70). Oxford: Published by Elsevier Inc. 
MacDonald, J. M., McBride, W. (2010). The Transformation of U.S. Livestock Agriculture: Scale, Efficiency and Risks. In: J. M. Daigle (Ed.), Transformation of U.S. Animal Agriculture (p. 162-164). New York: Nova Science Publishers.

MacDonald, J. M., O’Donoghue, E. J., McBride, W. D., Nehring, R. F., Sandretto, C. L., Mosheim, R. (2010). Profits, Costs, and the Changing Structure of Dairy Farming. In: J. M. Daigle (Ed.), Transformation of U.S. Animal Agriculture (p. 76). New York: Nova Science Publishers.

Marsden, T., Banks, J., Bristow, G. (2000). Food Supply Chain Approaches: Exploring their Role in Rural Development, Soc. Rural., 40, 424-438.

Martinez, S., Hand, M., Da Pra, M., Pollack, S., Ralston, K., Smith, T., Vogel, S., Clark, S., Lohr, L., Low, S., Newman, C. (2010). Local Food Systems: Concepts, Impacts, and Issues, Economic Research Report (p. 3, 47). U.S. Department of Agriculture.

Parfitt, J., Barthel, M., Macnaughton, S. (2010). Food waste within food supply chains: quantification and potential for change to 2050. Phil. Trans. R. Soc. B, 365, 3065-3081.

Parzonko, A. (2013). Globalne i lokalne uwarunkowania rozwoju produkcji mleka [Global and local conditions for the development of milk production] (p. 134, 200). Warszawa: Wyd. SGGW [in Polish].

Pietrzak, M. (2006). Efektywność finansowa spółdzielni mleczarskich - koncepcja oceny [Financial effectiveness of dairy cooperatives - the concept of evaluation] (p. 155). Warszawa: Wyd. SGGW [in Polish].

Pilgrim, F. J. (1957). The Components of Food Acceptance and Their Measurement. Am. J. Clinic. Nutr., 5, 171-175.

Ross, N. J., Anderson, M. D., Goldberg, J. P., Houser, R., Rogers, B. L. (1999). Trying and Buying Locally Grown Produce at the Workplace: Results of a Marketing Intervention. Am. J. Alter. Agric., 14(4), p. 171-179.

Seremak-Bulge, J. (Ed.). (2005). Rozwój rynku mleczarskiego i zmiany jego funkcjonowania w latach 1990-2005
[Development of the dairy market and changes in its functioning in the years 1990-2005] (p. 114-116). Warszawa: IERiGŻ-PIB [in Polish].

Shimp, T. A., Sharma, S. (1987). Consumer Ethnocentrism: Construction and Validation of the CETSCALE. J. Market. Res., 24, 280-289.

Steenkamp, J.-B. E. M. (1997). Dynamics in Consumer Behavior with Respect to Agricultural and Food Products. In: B. Wierenga, A. Tilburg, K. G. Grunert, , J.-B. E. M. Steenkamp, M. Wedel (Eds.), Agricultural Marketing and Consumer Behavior in a Changing World (p. 143-188). New York: Springer US.

Swenson, D. (2009). Investigating the Potential Economic Impacts of Local Foods for Southeast Iowa. Leop. Cent. Pubs Papers, 66, 1-29.

Sznajder, M. (1999). Ekonomia mleczarstwa [Economy of the milk market] (p. 173). Poznań: Wyd. AR w Poznaniu [in Polish].

Sznajder, M. (Ed.) (2016). Atlas Firm Przemysłu Spożywczego 2014/2015 [Atlas of Food Industry in Poland 2014/2015]. Przeźmierowo: Horyzont Mateusz Sznajder.

Wrzosek, M., Bilska, B., Kołożyn-Krajewska, D., Krajewski, K. (2014). Ograniczenie strat produktów mleczarskich w handlu detalicznym jako element społecznie odpowiedzialnego biznesu [Reducing food losses in the dairy sector as part of corporate social responsibility]. Rocz. Nauk. SERiA, XVI (6), 541-545 [in Polish].

Zalewski, A. (2000). Gospodarka mleczarska a rynek [Dairy economy and the market]. Warszawa: IERiGŻ-PIB [in Polish].

Zuba-Ciszewska, M. (2016). Zaufanie w tworzeniu wartości spółdzielni [The trust in the creation of the value of the cooperative]. Stud. Ekon. Zesz. Nauk. UE Katow., 259, 175-184 [in Polish]. 